FITRAH Jurnal Kajian Ilmu-ilmu Keislaman

Vol. 02 No. 2 Desember 2016

e-ISSN : 2460-2345, p-ISSN: 2442-6997

Web: jurnal.iain-padangsidimpuan.ac.id/index.php/F

\title{
IMPLEMENTASI PENILAIAN AUTENTIK KURIKULUM 2013 PADA PEMBELAJARAN PENDIDIKAN AGAMA ISLAM DI MADRASAH TSANAWIYAH NEGERI 2 PALANGKA RAYA
}

\author{
ABDULLAH, S.Pd.I., M.Pd.I. \\ Lecturer at State Institute for Islamic Studies Palangka Raya \\ email : abdullah@iain-palangkaraya.ac.id
}

\begin{abstract}
Abstrak
Kurikulum 2013 salah satu bentuk pembaharuan dan inovasi pendidikan di Indonesia. Penilaian autentik merupakan salah satu elemen penting yang harus dilaksanakan dalam proses pembelajaran. Penelitian ini bertujuan mengetahui implementasi penilaian autentik pada pembelajaran PAI dan mengetahui kendala-kendala yang dihadapi guru PAI dalam mengimplementasikannya di MTsN 2 Palangka Raya. Peneltian ini merupakan penelitian deskriptif kualitatif, dengan teknik pengumpulan data observasi, wawancara, dan dokumentasi. Data dianalisis melalui reduksi data, penyajian data, dan penarikan kesimpulan. Teknik pemeriksaan keabsahan data menggunakan ketekunan pengamatan, trianggulasi, dan pemeriksaan teman sejawat melalui diskusi. Hasil penelitian menunjukkan bahwa : 1) Implementasi penilaian autentik Kurikulum 2013 yang dilakukan oleh guru PAI di MTsN 2 Palangka Raya belum berjalan secara optimal. 2) Kendala yang dihadapi guru PAI dalam mengimplementasikan penilaian autentik adalah kendala umum dan kendala khusus. Kendala umum adalah ketersedian buku dalam menunjang pembelajaran. Sedangkan kendala khusus adalah kemampuan guru: Pertama, kendala teknis yang terkait kemampuan guru dalam menggunakan aplikasi penilaian; kedua kendala non teknis, yaitu kemampuan guru memahami penilaian autentik.
\end{abstract}

Kata Kunci: Penilaian Autentik, Implementasi, Kendala

\begin{abstract}
Curriculum 2013 is one form of reformation and innovation of education in Indonesia. Authentic assessment is one of the essential elements that must be implemented in the learning process. This study aims to determine the implementation of authentic assessment on PAI learning and knowing the constraints faced by PAI teachers in implementing them in MTsN 2 Palangkaraya. This research is a qualitative descriptive study, by using observation, interviews, and documentation as techniques of collecting the data. Then, the data were analyzed through data reduction, data presentation, and conclusion. To check the data trustworthiness, the researher used persistence observation, triangulation, and inspection peers through discussion. The results showed that: 1) Implementation of Curriculum 2013 authentic assessment conducted by the teacher PAI in
\end{abstract}


FITRAH Jurnal Kajian Ilmu-ilmu Keislaman

Vol. 02 No. 2 Desember 2016

MTsN 2 Palangkaraya didnot run optimally; 2) the problems of PAI teachers in implementing is in common constraints and special constraints. A common constraint is the availability of books in supporting learning. While the special constraints are the ability of teachers about the technical problems related to the ability of teachers to use assessment application; and the non-technical constraints, it is the ability of teachers to understand authentic assessment itself.

Keywords: Authentic Assessment, Implementation, Obstacles

\section{PENDAHULUAN}

Usaha mewujudkan cita-cita luhur bangsa Indonesia dilakukan oleh pemerintah Indonesia dengan terus melakukan pembaharuan dan inovasi dalam bidang pendidikan. Salah satu bentuk pembaharuan dan inovasi pendidikan di Indonesia saat ini yaitu dengan diterapkannya Kurikulum 2013. Kurikulum 2013 merupakan kurikulum baru yang berfungsi sebagai penyempurnan kurikulum sebelumnya, yaitu Kurikulum Tingkat Satuan Pendidikan (KTSP).

Implementasi kurikulum 2013 yang diterapkan di sekolah masih banyak terdapat kendala, mulai dari kesiapan madrasah, baik sarana dan prasarana dalam menunjang proses belajar mengajar, kesiapan guru, buku paket siswa yang belum didistribusikan ke madrasah, beban mengajar guru yang terlalu banyak. Sampai dengan sistem penilaian pembelajaran yang begitu rumit, yang dikenal dengan penilaian autentik.

Penilaian autentik menjadi salah satu penekanan dalam Kurikulum 2013. Kunandar mengungkapkan bahwa melalui Kurikulum 2013 penilaian autentik menjadi penekanan yang serius dimana guru harus menerapkan penilaian autentik dalam setiap proses pembelajaran. Kunandar ${ }^{1}$ juga mengungkapkan bahwa penilaian bertujuan untuk mengukur keberhasilan pembelajaran yang dilakukan oleh guru dan sekaligus mengukur keberhasilan siswa dalam penguasaan kompetensi yang telah ditentukan. Guru dapat melakukan refleksi dan evaluasi terhadap kualitas pembelajaran yang telah dilakukan melalui kegiatan penilaian.

Dalam Peraturan Menteri Pendidikan dan Kebudayaan Republik Indonesia Nomor 66 Tahun 2013 Tentang Standar Penilaian Pendidikan menjelaskan penilaian autentik merupakan penilaian yang dilakukan secara

${ }^{1}$ Kunandar. Penilaian Autentik (Penilaian Hasil Belajar Peserta Didik Berdasarkan Kurikulum 2013): Suatu Pendekatan Praktis disertai dengan Contoh, Ed. Rev. (Jakarta: Rajawali Pers, 2014.), hlm. 35 
komprehensif untuk menilai mulai dari masukan (input), proses, dan keluaran (output) pembelajaran. Penilaian otentik dilakukan oleh guru secara berkelanjutan.

Implementasi penilaian autentik di madrasah terutama pada pembelajaran pendidikan Agama Islam (PAI) yaitu Al-Qur'an Hadis, Akidah Akhlak, Fiqh, dan Sejarah Kebudayaan Islam, bagi seorang guru memerlukan waktu yang banyak pada pengisian format instrumen baik pada aspek sikap, pengetahuan, dan keterampilan, maupun ketika merekapitulasi nilai akhir siswa pada akhir pembelajaran. Untuk memudahkan penilaian, guru juga harus menghafal semua peserta didik yang akan dinilai secara tepat sehingga memudahkan pemberian nilai secara tepat pula.

Guru juga dituntut lebih kreatif dalam mengembangkan soal berikut rubrik dan penskorannya sesuai dengan kebutuhan peserta didik, dan guru diharapkan untuk memiliki catatan sikap atau nilai-nilai karakter yang dimiliki peserta didik selama dalam proses pembelajaran. Tentu hal ini menambah beban guru dalam melaksanakan penilaian, karena guru dalam hal ini harus mampu mendesain ulang soal berikut rublik dan penskoran dalam penilaian autentik.

Lokasi penilitian yang dipilih untuk melihat implementasi penilaian autentik ialah di MTsN 2 Palangka Raya. Alasannya MTsN 2 Palangka Raya telah menerapakan Kurikulum 2013 pada pembelajaran PAI sejak tahun ajaran 2014/2015 yang dimulai pada kelas VII, untuk dijadikan pilot project kurikulum 2013. (Wawancara tanggal 04-03-2016)

Berdasarkan observasi awal (04-03-2016) terlihat bahwa pelaksanaan penilaian autentik di madrasah tersebut masih memiliki kendala. Kendala yang paling dominan terdapat pada guru. Sebagaimana pernyataan dari guru yang menyebutkan bahwa selama ini sosialisasi tentang penilaian autentik masih belum dapat dipahami oleh guru-guru, sehingga mereka harus mempelajari sendiri tentang penilaian autentik. Kondisi tersebut yang masih dirasa sulit bagi guru karena harus mempelajari sendiri tentang bagaimana melakukan penilaian autentik dengan prosedur yang benar.

Berdasarkan latarbelakang tersebut, perlu diadakan penelitian dengan rumusan masalah: 1) Bagaimana implementasi penilaian autentik pada pembelajaran PAI di MTsN 2 Palangka Raya? 2) Apa saja kendala yang dihadapi guru dalam mengimplementasikan penilaian autentik pada pembelajaran PAI?

Penelitian ini bertujuan mengembangkan wawasan bagi semua pihak 
yang mempunyai peran dalam penilaian autentik, khususnya bagi guru PAI; sebagai bahan refleksi dan evaluasi bagi guru PAI dalam implementasi penilaian autentik; dan menjadi bahan pertimbangan madrasah maupun pemerintah dalam mengembangkan kualitas guru PAI terkait dengan penilaian autentik.

\section{LANDASAN TEORI}

\section{Definisi Penilaian Autentik}

Kunandar $^{2}$ menjelaskan bahwa penilaian autentik merupakan kegiatan menilai siswa yang menekankan pada apa yang seharusnya dinilai secara nyata, baik proses maupun hasil dengan berbagai instrumen penilaian yang disesuaikan dengan tuntutan kompetensi yang ada. Sementara itu, Imas Kurinasih $^{3}$ juga menjelaskan bahwa penilaian autentik merupakan penilaian yang dilakukan secara komprehensif untuk menilai mulai dari masukan (input), proses, dan keluaran (output) pembelajaran, yang meliputi ranah sikap, pengetahuan, dan keterampilan.

Berdasarkan pengertian di atas, maka dapat dinyatakan bahwa penilaian autentik merupakan penilaian yang dilakukan secara menyeluruh yaitu dalam ranah sikap, baik sikap spiritual maupun sikap sosial, pengetahuan, dan keterampilan, untuk menilai mulai dari masukan (input), proses, dan keluaran (output) pembelajaran.

\section{Ruang lingkup, Teknik Penilaian Autentik}

1. Ruang Lingkup Penilaian Autentik

Penilaian hasil belajar peserta didik mencakup kompetensi sikap, pengetahuan, dan keterampilan yang dilakukan secara berimbang sehingga dapat digunakan untuk menentukan posisi relatif setiap peserta didik terhadap standar yang telah ditetapkan. Menurut Imas Kurinasih dan Berlin Sani $^{4}$ bahwa penilaian autentik siswa mencakup kompetensi sikap, pengetahuan, dan keterampilan yang dilakukan secara berimbang. Kunandar ${ }^{5}$ juga menyatakan bahwa penilaian autentik siswa mencakup kompetensi sikap, pengetahuan, dan keterampilan. Pendapat para ahli tersebut diperkuat

${ }^{2}$ Kunandar. 2014. Penilaian Autentik...... hlm. 35

${ }^{3}$ Imas Kurinasih dan Berlin Sani.. Implementasi Kurikulum 2013: Konsep dan Penerapan. (Surabaya: Kata Pena, 2014). hlm.48

${ }^{4}$ Imas Kurinasih dan Berlin Sani. Implementasi Kurikulum 2013:....., hlm. 52

${ }^{5}$ Kunandar. Penilaian Autentik...... hlm. 35 
dengan adanya Salinan Lampiran Permendikbud Nomor 104 tahun $2014^{6}$ menerangkan bahwa ruang lingkup dalam penilaian autentik mencakup kompetensi sikap (spiritual dan sosial), pengetahuan, dan keterampilan.

2. Teknik dan Instrumen Penilaian Autentik

a. Penilaian Kompetensi Sikap

Guru dapat melakukan penilaian kompetensi sikap siswa dengan menggunakan berbagai cara, antara lain melalui observasi, penilaian diri, penilaian teman sejawat, penilaian jurnal.

1) Observasi

Menurut Kunandar7 Observasi merupakan teknik penilaian yang dilakukan secara berkesinambungan dengan menggunakan indera, baik secara langsung maupun tidak langsung dengan menggunakan pedoman observasi yang berisi sejumlah indikator perilaku yang diamati. Kokom Komalasari, ${ }^{8}$ juga menyebutkan bahwa observasi dapat dilakukan dengan menggunakan daftar cek yang memuat perilaku- perilaku tertentu yang diharapkan muncul dari siswa.

2) Penilaian Diri

Menurut Kokom Komalasari ${ }^{9}$ penilaian diri adalah suatu teknik penilaian dengan cara meminta siswa untuk mengemukakan kelebihan dan kekurangan dirinya dalam konteks pencapaian kompetensi sikap, baik sikap spiritual maupun sosial.

3) Penilaiain Teman Sejawat

Penilaian teman sebaya merupakan teknik penilaian yang dapat digunakan untuk mengukur tingkat pencapaian kompetensi sikap dengan cara meminta siswa untuk saling menilai satu sama lain. Menurut Kunandar ${ }^{10}$ bahwa instrumen yang digunakan dalam penilaian teman sebaya berupa lembar penilaian teman sebaya dalam bentuk angket atau kuesioner. Penilaian teman sebaya dapat dinyatakan merupakan teknik penilaian yang dapat digunakan untuk mengukur tingkat pencapaian kompetensi sikap dengan cara meminta siswa untuk

${ }^{6}$ Salinan Lampiran Permendikbud Nomor 104 tahun 2014 tentang Penilaian Hasil Belajar oleh Pendidik pada Pendidikan Dasar dan Pendidikan Menengah.

${ }^{7}$ Kunandar. 2014. Penilaian Autentik...... hlm. 121

${ }^{8}$ Kokom Komalasari. Pembelajaran Kontekstual: Konsep dan Aplikasi. (Bandung: PT Refika Aditama. 2013(, hlm. 157

${ }^{9}$ Kokom Komalasari. Pembelajaran Kontekstual:......, hlm. 157

${ }^{10}$ Kunandar. Penilaian Autentik...... hlm. 144 
saling menilai satu sama lain.

4) Penilaian Jurnal

Kunandar ${ }^{11}$ menyebutkan bahwa penilaian jurnal merupakan catatan pendidik di dalam dan di luar kelas yang berisi informasi hasil pengamatan tentang kekuatan dan kelemahan siswa yang berkaitan dengan sikap dan perilaku. Sementara itu, Kokom Komalasri ${ }^{12}$ menyatakan bahwa perilaku siswa dapat diamati dengan menggunakan buku catatan khusus tentang kejadian-kejadian yang berkaitan dengan siswa selama di sekolah. Dengan demikian jurnal merupakan kumpulan rekaman catatan guru dan/atau tenaga kependidikan di lingkungan sekolah tentang sikap dan perilaku positif atau negatif, selama dan di luar proses pembelajaran.

Bentuk penilaian jurnal ini lebih bersifat insidental, oleh karena itu format penilaian yang dipersiapkan yang mengacu Permendikbud Nomor 104 tahun 2014 tentang Penilaian Hasil Belajar oleh Pendidik pada Pendidikan Dasar dan Pendidikan Menengah memuat hari, tanggal, kejadian baik itu bentuk positif maupun negatif kemudian keterangan.

b. Penilaian Kompetensi Pengetahuan

a) Tes Tertulis

Kunandar $^{13}$ menjelaskan bahwa tes tertulis merupakan tes dimana soal dan jawaban yang diberikan kepada siswa dalam bentuk tulisan. Dalam menjawab soal, siswa tidak selalu merespon dalam bentuk menulis jawaban, tetapi dapat juga dalam bentuk yang lain, misalnya memberi tanda, mewarnai, menggambar, dan lain-lain. Dengan demikian tes tertulis merupakan tes dimana soal dan jawaban yang diberikan kepada siswa dalam bentuk tulisan.

b) Tes lisan

Tes lisan menurut Kunandar ${ }^{14}$ merupakan tes dimana guru memberikan pertanyaan langsung kepada siswa secara verbal (bahasa lisan) dan ditanggapi oleh siswa secara langsung dengan menggunakan bahasa verbal (lisan) juga. Dengan demikian tes lisan merupakan tes

\footnotetext{
${ }^{11}$ Kunandar. Penilaian Autentik...... hlm. 151

${ }^{12}$ Kokom Komalasari. Pembelajaran Kontekstual:......, hlm.157

${ }^{13}$ Kunandar. Penilaian Autentik...... hlm. 173

${ }^{14}$ Ibid. hlm. 225
} 
dimana guru dan siswa melakukan tanya jawab secara langsung dengan menggunakan bahasa verbal (lisan).

c) Penugasan

Menurut Kunandar ${ }^{15}$ penugasan merupakan penilaian yang bertujuan untuk pendalaman terhadap penguasaan kompetensi pengetahuan yang telah dipelajari melalui proses pembelajaran. Instrumen penugasan berupa pekerjaan rumah dan/atau projek yang dikerjakan secara individu atau kelompok sesuai dengan karakteristik tugas.

c. Penilaian Kompetensi Keterampilan

1) Penilaian Unjuk Kerja/Kinerja/Praktik

Penilaian unjuk kerja menurut Kunandar ${ }^{16}$ merupakan penilaian yang meminta siswa untuk mendemonstrasikan dan mengaplikasikan pengetahuan ke dalam konteks yang sesuai dengan kriteria yang ditetapkan. Penilaian unjuk kerja dilakukan dengan mengamati kegiatan siswa dalam melakukan sesuatu. Dengan demikian penilaian unjuk kerja merupakan penilaian yang dilakukan dengan mengamati kegiatan siswa dalam melakukan sesuatu.

2) Penilaian Projek

Kunandar ${ }^{17}$ berpendapat bahwa penilaian projek merupakan kegiatan penilaian terhadap suatu tugas yang meliputi pengumpulan, pengorganisasian, pengevaluasian, dan penyajian data yang harus diselesaikan siswa baik secara individu atau kelompok dalam waktu atau periode tertentu. Dengan demikian penilaian projek adalah kegiatan penilaian terhadap suatu tugas yang harus diselesaikan siswa baik secara individu atau kelompok dalam waktu atau periode tertentu.

Kementerian Agama ${ }^{18}$ menyebutkan bahwa produk akhir dari sebuah proyek sangat mungkin memerlukan penilaian khusus. Penilaian produk dari sebuah proyek dimaksudkan untuk menilai kualitas dan bentuk hasil akhir secara holistik dan analitik.Penilaian produk dimaksud meliputi penilaian atas kemampuan peserta didik menghasilkan produk, seperti hasil karya seni (gambar, lukisan, kaligrafi, dan lain-lain), karya

\footnotetext{
${ }^{15}$ Ibid. Penilaian Autentik...... hlm. 231

${ }^{16}$ Ibid.. Penilaian Autentik..... hlm. 236

${ }^{17}$ Ibid.. Penilaian Autentik...... hlm. 286

${ }^{18}$ Kementerian Agama RI.. Penilaian Proses dan Hasil Belajar Modul VI PLPG. 2015. hlm. 12
} 
artikel tentang perilaku terpuji, tasamuh dan lain-lain.

3) Penilaian Portofolio

Kunandar ${ }^{19}$ menyatakan bahwa penilaian portofolio merupakan penilaian berkelanjutan yang didasarkan pada kumpulan informasi yang menunjukkan perkembangan kemampuan siswa dalam periode tertentu. Dengan demikian penilaian portofolio pada dasarnya menilai karyakarya siswa pada satu periode tertentu. Oleh karena itu, portofolio dapat memperlihatkan perkembangan kemajuan belajar siswa melalui karyanya, misalnya karangan, puisi, surat, gambar, hasil diskusi, hasil membaca buku, dan lain sebagainya.

3. Keunggulan dan kelemahan Penilaian Autentik

Kokom Komalasari ${ }^{20}$ menjelaskan keunggulan penilaian autentik sebagai berikut.

a. Penilaian autentik dapat digunakan sebagai pengumpulan informasi kemajuan belajar siswa, baik formal maupun informal yang diadakan dalam suasana menyenangkan dan memungkinkan adanya kesempatan bagi siswa untuk menunjukkan kemampuan dan keterampilannya.

b. Prestasi belajar siswa tidak dibandingkan dengan prestasi kelompok, tetapi prestasi atau kemampuan yang dimiliki setiap siswa dibandingkan dengan prestasi sebelumnya. Oleh karena itu siswa tidak didiskriminasi (masuk rangking atau tidak) tetapi dibantu untuk mencapai apa yang diharapkan.

c. Pengumpulan informasi dilakukan dengan berbagai cara agar gambaran tentang perkembangan belajar siswa dapat lebih terdeteksi oleh guru. Guru dapat menggunakan berbagai macam cara atau teknik penilaian untuk mengetahui perkembangan belajar siswa secara menyeluruh.

d. Siswa tidak hanya dilatih untuk memilih jawaban yang tersedia, tetapi dilatih untuk memecahkan masalah yang dihadapi dengan caranya sendiri.

e. Pengumpulan informasi digunakan untuk menentukan perlu tidaknya bantuan yang diberikan kepada siswa secara terencana, bertahap, dan berkesinambungan, berdasarkan fakta dan bukti yang memadai.

f. Penilaian tidak hanya dilakukan setelah proses pembelajaran, tetapi penilaian dapat dilakukan selama proses pembelajaran. Jadi, sepanjang proses pembelajaran dari awal sampai akhir guru selalu melakukan

${ }^{19}$ Kunandar. Penilaian Autentik...... hlm. 294

${ }^{20}$ Kokom Komalasari. Pembelajaran Kontekstual:......, hlm. 150 
penilaian.

g. Kriteria penilaian karya siswa dapat dibahas guru dengan siswa sebelum karya tersebut dikerjakan, agar siswa mengetahui patokan penilaian yang akan digunakan atau berusaha mencapai harapan guru.

Dalam penilaian autentik selain memiliki beberapa keunggulan penilaian autentik juga memiliki beberapa kelemahan. Adapun keunggulan dan kelemahan dalam penilaian autentik tersebut akan dijabarkan oleh Ismet Basuki dan Hariyanto ${ }^{21}$ pada tabel berikut.

Tabel 1 : Keunggulan dan Kelemahan Penilaian Autentik

\begin{tabular}{lll}
\hline No. & \multicolumn{1}{c}{ Keunggulan } & \multicolumn{1}{c}{ Kelemahan } \\
\hline 1. & $\begin{array}{l}\text { Berfokus pada keterampilan } \\
\text { analisis dan keterpaduan } \\
\text { pengetahuan. }\end{array}$ & $\begin{array}{l}\text { Memerlukan waktu yang intensif } \\
\text { untuk mengelola, memantau, dan } \\
\text { melakukan koordinasi. }\end{array}$ \\
\hline 2. & Meningkatkan kreativitas. & $\begin{array}{l}\text { Sulit untuk dikoordinasikan dengan } \\
\text { standar pendidikan yang telah }\end{array}$ \\
\hline 3. & Merefleksikan keterampilan & $\begin{array}{l}\text { Menantang guru untuk memberikan } \\
\text { skema pemberian nilai yang }\end{array}$ \\
\hline 4. & Mendorong kerja kolaboratif. & $\begin{array}{l}\text { Sifat subyektif dalam pemberian nilai } \\
\text { akan cenderung menjadi bias. }\end{array}$ \\
\hline 5. & $\begin{array}{l}\text { Meningkatkan } \\
\text { keterampilan lisan dan }\end{array}$ & $\begin{array}{l}\text { Sifat penilaian yang unik mungkin } \\
\text { tidak dikenali siswa. }\end{array}$ \\
\hline 6. & $\begin{array}{l}\text { Langsung menghubungkan } \\
\text { kegiatan asesmen, kegiatan } \\
\text { pengajaran, dan tujuan }\end{array}$ & $\begin{array}{l}\text { Dapat bersifat tidak praktis untuk } \\
\text { kelas yang berisi banyak siswa. }\end{array}$ \\
\hline 7. & $\begin{array}{l}\text { Menekankan kepada } \\
\text { keterpaduan pembelajaran } \\
\text { di sepanjang waktu. }\end{array}$ & $\begin{array}{l}\text { Hal yang menantang untuk } \\
\text { mengembangkan berbagai jenis } \\
\text { materi ajar dan berbagai kisaran }\end{array}$ \\
\hline
\end{tabular}

${ }^{21}$ Ismet Basuki dan Hariyanto. Asesmen Pembelajaran. (Bandung: PT Remaja Rosdakarya, 2014.) hlm.175 
FITRAH Jurnal Kajian Ilmu-ilmu Keislaman

Vol. 02 No. 2 Desember 2016

\section{Pendidikan Agama Islam di Madrasah Tsanawiyah}

Abdul Majid ${ }^{22}$ mendefinisikan pendidikan agama Islam adalah upaya sadar dan terencana dalam menyiapkan peserta didik untuk mengenal, memahami, menghayati, hingga mengimani, ajaran Islam, dibarengi dengan tuntunan untuk menghormati penganut agama lain dalam hubungannya dengan kerukunan antar umat beragama hingga terwujud kesatuan dan persatuan bangsa. Menurut Zakiyah Daradjat ${ }^{23}$ pendidikan agama Islam adalah suatu usaha untuk membina dan mengasuh peserta didik agar senantiasa dapat memahami ajaran Islam secara menyeluruh. Lalu menghayati tujuan, yang pada akhirnya dapat mengamalkan serta menjadikan Islam sebagai pandangan hidup.

Jadi pendidikan agama Islam merupakan usaha sadar yang dilakukan pendidik dalam rangka mempersiapkan peserta didik untuk meyakini, memahami, dan mengamalkan ajaran Islam melalui kegiatan bimbingan, pengajaran atau pelatihan yang telah ditentukan untuk mencapai tujuan yang telah ditetapkan. Hal ini sesuai dengan firman Allah SWT, didalam Al-Qur'an surat An-Nahl ayat 78:

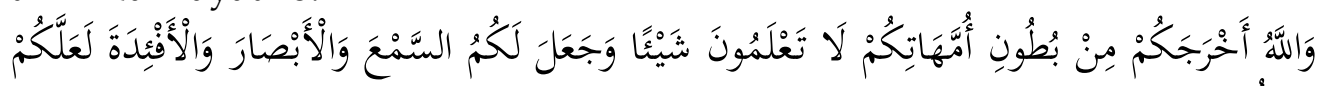

Artinya: “Dan Allah mengeluarkan kamu dari perut ibumu dalam keadaan tidak mengetahui sesuatupun, dan Dia memberi kamu pendengaran, penglihatan dan hati agar kamu bersyukur"

Sesuai dengan ayat tersebut di atas jelaslah bahwasanya usaha mengubah tingkah laku individu dalam kehidupan pribadinya atau kehidupan kemasyarakatan dan kehidupan dalam alam sekitarnya melalui proses pendidikan sebagai upaya membimbing dan mengarahkan kemampuankemampuan dasar dan belajar manusia baik sebagai makhluk maupun dalam hubungannya dengan alam sekitar.

Adapun Pendidikan Agama Islam di Madrasah Tsanawiyah terdiri dari kelompok mata pelajaran meliputi : Al-Qura'an Hadis, Akidah Akhlak, Fiqh, dan Sejarah Kebudayaan Islam. Berikut ini tabel susunan mata pelajaran dan alokasi waktu untuk Madrasah Tsanawiyah berdasarkan Keputusan Menteri Agama Nomor 165 Tahun 2014 Tentang Kurikulum 2013 Mata Pelajaran Pendidikan

\footnotetext{
${ }^{22}$ Abdul Majid. 2007. Perencanaan Pembelajaran Mengembangkan Standar Kompetensi Guru. Bandung: PT Remaja RosdaKarya. Hlm.103

${ }^{23}$ Zakiah Darajat. 2009. Ilmu Pendidikan Islam. Jakarta : Bumi Aksara, hlm.87
} 
Agama Islam dan Bahasa Arab di Madrasah. ${ }^{24}$

Tabel 2 : Mata Pelajaran Alokasi Waktu Madrasah Tsanawiyah

\begin{tabular}{|c|c|c|c|}
\hline \multirow[t]{2}{*}{ MATA PELAJARAN } & \multicolumn{3}{|c|}{$\begin{array}{c}\text { ALOKASI WAKTU } \\
\text { BELAJAR } \\
\text { PER MINGGU } \\
\end{array}$} \\
\hline & VII & VIII & IX \\
\hline \multicolumn{4}{|l|}{ Kelompok A } \\
\hline \multicolumn{4}{|l|}{ 1. Pendidikan Agama Islam } \\
\hline a. Al-Qur' an Hadis & 2 & 2 & 2 \\
\hline b. Akidah Akhlak & 2 & 2 & 2 \\
\hline c. Fiqih & 2 & 2 & 2 \\
\hline d. Sejarah Kebudayaan Islam & 2 & 2 & 2 \\
\hline 2. Pendidikan Pancasila dan Kewarganegaraan & 3 & 3 & 3 \\
\hline 3. Bahasa Indonesia & 6 & 6 & 6 \\
\hline 4. Bahasa Arab & 3 & 3 & 3 \\
\hline 5. Matematika & 5 & 5 & 5 \\
\hline 6. Ilmu Pengetahuan Alam & 5 & 5 & 5 \\
\hline 7. Ilmu Pengetahuan Sosial & 4 & 4 & 4 \\
\hline 8. Bahasa Inggris & 4 & 4 & 4 \\
\hline \multicolumn{4}{|l|}{ Kelompok B } \\
\hline 1. Seni Budaya & 3 & 3 & 3 \\
\hline 2. Pendidikan Jasmani, Olahraga dan Kesehatan & 3 & 3 & 3 \\
\hline 3. Prakarya & 2 & 2 & 2 \\
\hline Jumlah Alokasi Waktu Per Minggu & 46 & 46 & 46 \\
\hline
\end{tabular}

Beban belajar merupakan keseluruhan kegiatan yang harus diikuti peserta didik dalam satu minggu, satu semester, dan satu tahun pembelajaran

1. Beban belajar di Madrasah Tsanawiyah dinyatakan dalam jam pembelajaran per minggu. Beban belajar satu minggu Kelas VII, VIII, dan IX adalah 46 jam pembelajaran. Durasi setiap satu jam pembelajaran adalah 40 menit.

2. Beban belajar di Kelas VII, VIII, dan IX dalam satu semester paling sedikit 18

\footnotetext{
${ }^{24}$ Keputusan Menteri Agama Nomor 165 Tahun 2014 Tentang Kurikulum 2013 Mata Pelajaran Pendidikan Agama Islam dan Bahasa Arab di Madrasah.
} 
minggu dan paling banyak 20 minggu.

3. Beban belajar di kelas IX pada semester ganjil paling sedikit 18 minggu dan paling banyak 20 minggu.

4. Beban belajar di kelas IX pada semester genap paling sedikit 14 minggu dan paling banyak 16 minggu.

5. Beban belajar dalam satu tahun pelajaran paling sedikit 36 minggu dan paling banyak 40 minggu.

\section{METODE PENELITIAN}

Jenis penelitian yang dilakukan adalah penelitian kualitatif. Penelitian ini bersifat deskriptif kualitatif, yaitu penelitian yang menghasilkan data deskriptif berupa kata-kata tertulis atau lisan dari orang-orang dan perilaku yang diamati.

Subyek pada penelitian ini ialah guru PAI, Kepala Madrasah, Wakil kepala madrasah bidang kurikulum, Mahasiswa Praktikan, dan siswa-siswi MTsN 2 Palangka Raya. Obyek dalam penelitian ini adalah implementasi penilaian autentik pada pembelajaran PAI .

Dalam pengumpulan data dan informasi peneliti menggunakan teknik observasi, wawancara, dan dokumentasi. Adapun analisis data yaitu: reduksi data, penyajian data, dan penarikan kesimpulan. Sedangkan teknik pemeriksaan keabsahan data menggunakan ketekunan pengamatan, trianggulasi, dan pemeriksaan teman sejawat melalui diskusi.

\section{DESKRIPSI HASIL PENELITIAN DAN PEMBAHASAN}

Implementasi Penilaian Autentik pada Pembelajaran PAI di MTsN 2 Palangka Raya

Penilaian Autentik merupakan salah satu komponen dari kurikulum 2013 yang harus dilaksanakan oleh guru pada saat pembelajaran. Tujuan utama dilaksanakannya penilaian autentik di sekolah ialah untuk mengetahui aspekaspek penting yang dimiliki anak untuk menunjang tercapainya tujuan pembelajaran yang telah ditetapkan.

Penerapan Kurikulum 2013 di MTsN 2 Palangka Raya telah dilaksanakan sejak tahun tahun ajaran 2014/2015 hingga sekarang yaitu tahun ajaran 2016/2017. Adapun pelaksanaannya dilakukan secara bertahap berdasarkan kelas masing-masing. Hal tersebut berdasarkan hasil wawancara yang menyebutkan bahwa: 
Pelaksanaan kurikulum 2013 di MTsN 2 Palangka Raya dilaksanakan secara bertahap pada masing-masing kelas. Pada tahun ajaran 2014/2015 dilaksanakan pada kelas VII (tujuh), tahun 2015/2016 pada kelas VIII (delapan) dan tahun 2016/2017 pada kelas IX (sembilan). Artinya Kurikulum 2013 pada tahun ajaran 2016/2017 telah diterapkan pada semua kelas. ${ }^{25}$

Berdasarkan hasil wawancara dapat diketahui bahwa Kurikulum 2013 telah diberlakukan pada MTsN 2 Palangka Raya sejak tahun ajaran 2014/2015. Akan tetapi sejak awal pelaksanaannya tidak diterapkan pada semua kelas, melainkan pada kelas-kelas tertentu yang dianggap siap. Awalnya sekolah menerapkan kurikulum 2013 pada tahun ajaran 2014/2015 di kelas VII, kemudian pada tahun ajaran 2015/2016 dilaksanakan di kelas VIII dan pada tahun ajaran 2016/2017 dilaksanakan di kelas IX. Terimplementasikannya kurikulum 2013 secara menyeluruh tidak serta merta mampu diaplikasikan oleh guru, khususnya Guru Pendidikan Agama Islam, salah satunya komponen kurikulum 2013 yang masih belum terlaksana secara maksimal yaitu aspek penilaian autentik.

Secara umum penilaian autentik kurikulum 2013 telah diketahui oleh para guru PAI melalui kegiatan pelatihan-pelatihan yang diselenggarakan oleh pemerintah baik dilaksanakan oleh Kementrian Agama Kota Palangka Raya maupun Provinsi Kalimantan Tengah. Berdasarkan Wakamad Kurikulum ${ }^{26}$ yang menyatakan bahwa:

Memang ada beberapa kegiatan pelatihan yang dilaksanakan baik itu di tingkat Kemenag kota maupun provinsi. Akan tetapi hanya biasa diikuti oleh sebagian guru. Adapun materi dalam pelatihan masih bersifat umum Artinya pelatihan ditujukan untuk semua guru yang mengajar mata pelajaran, bukan bersifat mata pelajaran tertentu, khusus mata pelajaran PAI.

Pernyataan sama juga disampaikan oleh Ibu Akramiah (Guru Mata Pelajaran Quran Hadis) (Wawancara tanggal 4-10-2016) menyebutkan bahwa untuk pelatihan khusus implementasi K13 guru PAI belum, namun secara umum sudah.

Berdasarkan hasil wawancara dapat diketahui bahwa melalui pelatihan sebagian guru diberikan bekal pengetahuan tentang Kurikulum 2013, dan diharapkan guru mampu menerapkan seluruh aspek yang terdapat dalam Kurikulum 2013 di Madrasah salah satunya aspek penilaian autentik. Namun

\footnotetext{
${ }^{25}$ wawancara (5-10-2016) dengan Kepala Madrasah MTsN 2 Palangka Raya

${ }^{26}$ wawancara (3-10-2016) dengan Wakamad Kurikulum MTsN 2 Palangkaraya
} 
dalam pelaksanaan pelatihan tidak terkhusus membahas aspek-aspek penting dalam Kurikulum 2013 diantaranya tentang teknis pelaksanaan penilaian autentik, sehingga guru hanya memahaminya secara umum dan otomatis pelakasnaanya di Madrasah masih belum terlaksana secara maksimal.

Menindak lanjuti kegiatan pelatihan yang dilaksanakan oleh pemerintah tentang Kurikulum 2013, Madrasah juga melaksanakan kegiatan pelatihan secara khusus untuk semua guru. Akan tetapi materi yang disampaikan banyak mengarah pada kompetensi inti dan model pembelajaran yang terdapat dalam kurikulum 2013. Sebagaimana pernyataan Wakamad Kurikulum (3-10-2016) yang menyebutkan bahwa: "Pelatihan yang dilaksanakan biasanya lebih cenderung kepada mempresentasikan materi pembelajaran yang bersifat teoritis sedangkan aspek yang bersifat praktek tidak terlalu banyak dibahas, contoh aspek yang bersifat praktek yaitu tentang penialain autentik ini."

Keterangan tersebut didukung oleh hasil dokumentasi tentang laporan kegiatan pelatihan yang diberi tema "In House Training Kurikulum 2013" yang dilaksanakan pada tahun 2015. Berdasarkan hasil wawancara dan dokumentasi dapat disimpulkan bahwa seluruh guru di MTsN 2 Palangka Raya telah diberikan bekal pengetahun tentang Kurikulum 2013 melalui pelatihan, meskipun pada kenyataannya masih belum mengarah pada aspek-aspek penting yang wajib dikuasi oleh guru seperti aspek penilaian autentik. Selain itu, dilihat dari waktu pelaksanaan pelatihan yaitu pada tahun 2015, menunjukan bahwa pada tahun 2016 sekolah masih belum dapat melaksanakan pelatihan sebagai tindak lanjut dari pelatihan yang dilaksanakan sebelumnya, sehingga pengetahuan yang dimiliki guru tentang kurikulum 2013 juga belum mengalami peningkatan.

Secara umum penilaian autentik Kurikulum 2013 mensyaratkan agar seorang guru tak hanya mampu dalam menilai aspek pengetahuan atau kognitif yang selama ini berjalan dan berkembang, melainkan menuntut kapasitas guru dalam menilai aspek lainnya yaitu aspek sikap (afektif) dan keterampilan (psikomotorik). Guru harus mampu menerapkan penilaian pada ketiga aspek tersebut selama proses pembelajaran berlangsung maupun saat pembelajaran usai dilaksanakan (output). ${ }^{27}$

27 Sunarti dan Selly Rahmawati. 2014. Penilaian dalam Kurikulum 2013; Membantu Guru dan Calon Guru Mengetahui Langkah-langkah Penilaian Pembelajaran. Yogyakarta: Andi Offset. Hlm.27 
Mengingat pentingnya dilaksanakan penilaian autentik di Madrasah, maka sejatinya guru harus mampu menerapkan seluruh bentuk penilaian yang terdapat dalam kurikulum 2013 dalam pembelajaran. Meski kompetensi yang dinilai bersifat terpadu yang didukung dengan bentuk penilaian yang komprehensif, namun dalam implementasinya di MTsN 2 Palangka Raya, tidak semua guru PAI dapat menerapkan semua bentuk penilaian untuk mengukur kompetensi sikap, pengetahuan dan keterampilan siswa dalam pembelajaran. Hal tersebut disebabkan oleh kemampuan guru PAI dalam memahami penilaian autentik, karakteristik mata pelajaran dan kendala teknis yang dihadapi. Berikut akan digambarkan lebih rinci tentang implementasi penilaian autentik pada pembelajaran PAI di MTsN 2 Palangka Raya.

\section{Ranah Sikap}

Bentuk penilaian yang terdapat dalam ranah sikap mencakup observasi guru, penilaian antar diri, penilaian antar teman dan jurnal. Idealnya semua bentuk penialaian itu dapat dilaksanakan secara keseluruhan khususnya pada mata pelajaran PAI, akan tetapi pada kenyataannya guru masih belum mampu melaksanakannya secara maksimal sesuai dengan bentuk dan tahap penilaian yang telah ditetapkan.

Secara umum, bentuk penilaian sikap yang terdapat dalam kurikulum 2013 telah seutuhnya diketahui oleh Guru MTsN 2 Palangka Raya, Akan tetapi dalam implementasinya terdapat sebagian guru yang belum melaksanakannya secara maksimal baik dari segi mekanisme pelaksanaan penilaiannya maupun penyediaan instrumen penilaiannya. Sebagaimana pernyataan Ibu Mardiana yang menyebutkan bahwa:

Bentuk penilaian sikap itu ada observasi guru, diri sendiri, antar teman, jurnal guru. Akan tetapi semua bentuk penilaian itu dilaksanakan secara bersamaan. Misal, saya masuk kelas, penilaian antar teman itu langsung kita nilai aja sikapnya itu, begitu juga dengan tingkah laku terhadap guru. Penilaian diberikan secara langsung aja, kemudian kesimpulannya dicatat dalam rekam nilai ${ }^{28}$.

Pernyataan yang sama juga disampaikan oleh Ibu Lina ${ }^{29}$ menyebutkan bahwa: Pada dasarnya Guru itu menjalankan seutuhnya penilaian itu. Tapi di dalam kelas tidak serta merta bisa dilaksanakan kepada semua siswa, akan

\footnotetext{
${ }^{28}$ Wawancara dengan Mardiana, Guru Mata Pelajaran SKI. pada tanggal 3 - 10 - 2016.
}

${ }^{29}$ Wawancara dengan Lina. Guru Mata Pelajaran SKI, pada tanggal 6 - 10 - 2016. 
tetapi penilaian dilakukan secara bergilir. Karena K13 ini dari segi penilaiannya saja yang berbeda. Adapun aspek lain menurut saya sama saja.

Berdasarkan hasil observasi menunjukan bahwa: guru memahami dan melaksanakan bentuk-bentuk penilaian autentik ranah sikap diantaranya observasi, penilaian antar teman sejawat dan penilaian diri, akan tetapi mekanisme penilaian yang dilakukan oleh guru belum sesuai dengan standar penilaian autentik yang terdapat dalam kurikulum 2013. Adapun hasil dokumentasi membuktikan bahwa tidak tersedianya instrumen-instrumen penilaian yang seharusnya dipersiapkan oleh guru setiap melaksanakan pembelajaran dan disesuaikan dengan kompetensi yang ingin dicapai dalam mata pelajaran yang diampu oleh guru.

Melihat hasil wawancara, observasi dan dokumentasi dapat disimpulkan bahwasanya guru PAI di MTsN 2 Palangka Raya mengetahui dan memahami secara utuh bentuk penilaian autentik khususnya ranah sikap dalam kurikulum 2013, akan tetapi mekanisme penilainnya masih belum terlaksana secara maksimal dalam pembelajaran. Idealnya guru tidak hanya mengetahui dan memahami bentuk penilaian yang digunakan dalam menilai sikap siswa, tetapi guru juga harus mempersiapkan instrumen sebagai alat dokumentasi dan menerapkannya sesuai dengan langkah-langkah pelaksanaan penilaian autentik.

Mengingat penilaian autentik merupakan bagian penting dalam kurikulum 2013, oleh karena itu diharapkan bagi guru sebagai pendidik mampu mengimplementasikannya pada saat kegiatan pembelajaran berlangsung. Terkhusus bagi guru PAI, penialaian autentik menjadi sangat penting karena melalui penialain yang dilakukan guru dapat mengukur keberhasilan pembelajaran dan perkembangan sikap dan tingkah laku siswa.

Implementasi penilaian autentik dapat dikatakan baik apabila guru mampu melaksanakannya secara kesuluruhan bentuk penilaian yang telah ditetapkan. Adapun di MTsN 2 Palangka Raya implementasi penilaian autentik aspek sikap belum terlaksana secara maksimal. Berdasarkan hasil wawancara dengan Ibu Lili Rahmini ${ }^{30}$ menyebutkan bahwa: Untuk ranah sikap guru melakukan penilaian dalam bentuk observasi pada saat mengajar. Kami juga menggunakan blanko penilaian antar teman untuk menilai

${ }^{30}$ Wawancara dengan Lili Rahmini, Guru Mata Pelajaran Fiqih dan Akidah Akhlak, pada tanggal 4-10 - 2016 . 
penilaian sikapnya. Adapun untuk penilaian jurnal jarang terlaksana. Bagi Guru yang penting dapat melaksanakan tugas secara umum sesuai prosedur yang ditentukan.

Bapak M. Isra ${ }^{31}$ juga menyatakan bahwa: Kalo sikap itu antar teman. Kami menggunakan ada semacam blanko. Ada penilaian diri dan antar teman. Nilai-nilai itu dibandingkan, dirata-ratakan. Observasi guru ke siswa ketika mengajar. Mana yang aktif, mana yang tidak.

Pernyataan serupa juga di sampaikan oleh Bapak Supiani, S.Ag. ${ }^{32}$ (Guru Mata Pelajaran Akidah Akhlak) yang menjelaskan bahwa: Penilaian sikap dilakukan dengan mengamati perilaku siswa. Secara keseluruhan tidak semua instrumen penilaian yang tersedia dan dapat dilaksanakan pada saat pembelajaran. Jadi dalam hal ini Penilaian masih dilaksanakan secara bertahap.

Berdasarkan hasil observasi dan dokumentasi yang dilaksanakan pada saat pembelajaran terlihat bahwa guru belum maksimal melaksanakan semua bentuk penilaian untuk ranah sikap, karena hanya sebagian guru yang mampu mengimplementasikan penilaian autentik yang terdapat dalam kurikulum 2013. Observasi dapat dilaksanakan oleh guru, akan tetapi untuk instrumen observasinya tidak tersedia, sehingga aspek-aspek yang akan dinilai oleh guru tidak terarah dan tidak sesuai dengan kompetensi mata pelajaran. Adapun penilaian antar teman dan penilaian diri juga dapat dilaksanakan oleh guru, dalam proses ini guru mempersiapkan blanko penilaian untuk diberikan kepada siswa, penialain ini menuntut kejujuran siswa untuk mampu menilai teman sejawatnya maupun dalam menilai dirinya, akan tetapi dalam pelaksanaanya belanko yang dipersiapkan guru terkadang tidak sesuai dengan kompetensi mata pelajaran yang diampu oleh guru, karena guru menggunakan blanko penilaian yang didapatkan dari guru yang telah melaksanakannya. Sedangkan jurnal yang digunakan untuk mencatat peristiwa-peristiwa penting yang terjadi pada anak baik bentuk prestasi maupun permasalahan yang terjadi pada siswa juga belum dilaksanakan oleh guru.

\footnotetext{
${ }^{31}$ Wawancara dengan M. Isra , Guru Mata Pelajaran Fiqih, pada tanggal 6-10 - 2016.

32 Wawancara dengan Supiani, S.Ag., Guru Mata Pelajaran Akidah Akhlak, pada tanggal $5-10-2016$.
} 
Berdasarkan hasil observasi, dokumentasi dan wawancara dapat disimpulkan bahwa penilaian aspek sikap yang dilakukan oleh guru belum terlaksana dengan optimal, karena guru hanya melaksanakan sebagian bentuk penilaian aspek sikap diantaranya observasi, penilaian teman dan penilaian diri adapun penilaian bentuk jurnal belum dapat terlaksana. Hal tersebut disebabkan oleh keterbatasan kemampuan guru untuk menyediakan semua instrumen penilaian yang sesuai dengan bentuk penilaian pada aspek sikap. Idealnya guru harus membuat sendiri instrumen penilainnya berdasarkan kompetensi yang ingin dicapai dalam mata pelajaran yang diampu oleh guru. Khususnya mata pelajaran Aqidah Akhlak penialain sikap menjadi sangat penting untuk dilaksanakan, karena dapat dijadikan sebagai gambaran terhadap perkembangan akhlak siswa.

\section{Ranah Pengetahuan}

Aspek pengetahuan yang terdapat pada kurikulum 2013 terkandung dalam KI-3, bentuk penilaian ranah pengetahuan meliputi tes tertulis, tes lisan dan penugasan. Implementasi penilaian autentik ranah pengetahuan di MTsN 2 Palangka Raya secara keseluruhan dapat dilaksanakan oleh guru. Untuk mengetahui perkembangan pengetahuan anak guru melakukan tes melalui UTS, hafalan maupun tugas harian dan UAS. Terlaksananya penilaian autentik ini pada saat pembelajaran dikarenakan bentuk penilaian ini mudah dilaksanakan oleh guru. Sebagaimana hasil wawancara dengan Bapak Miftah Safingi, M.Pd ${ }^{33}$ menyebutkan bahwa: Penilaian yang mudah dilakukan itu penilaian ranah pengetahuan. Karena ukurannya ulangan harian, tugas, UTS, dan bentuk penilaiannya itu gak terlalu jauh dengan KTSP.

Selain itu, hasil wawancara dengan Bapak M. Isra ${ }^{34}$ menjelaskan bahwa: Untuk penilaian pengetahuan ini saya ambil beberapa penilaian dari ulangan harian, UTS, UAS, ditambah tugas-tugas, PR, seperti tugas di kelas maupun tugas kelompok. Namun ada sebagian guru ${ }^{35}$ menyatakan bahwa terimplementasinya penilaian autentik dalam pembelajaran jika tersedianya sarana pendukung pembelajaran, seperti buku pegangan guru, maupun pegangan siswa atau LKS. Sebagaimana hasil wawancara dengan Kelas IX (sembilan) baru diberlakukan tahun ini. Jadi apa yang dipelajari selama ini

${ }^{33}$ Wawancara dengan Miftah Safingi, Wakamad Bidang Kurikulum, pada tanggal 3 - 10 -

${ }^{34}$ Wawancara dengan M. Isra, Guru Mata Pelajaran Fiqih, pada tanggal 6-10 - 2016.

${ }^{35}$ Wawancara dengan guru lainnya pada tanggal 5-10-2016. 
bukunya belum ada. Sementara ini siswa menggunakan LKS dan buku yang di download.

Meskipun pada saat observasi tidak terlihat adanya kegitan tes yang diberikan guru kepada siswa, Akan tetapi hasil dokumentasi menemukan adanya raport yang digunakan guru untuk mendokumentasikan hasil dari tes yang dilakukan guru melalui UTS, UAS, hafalan dan tugas harian.

Berdasarkan hasil wawancara, observasi dan dokumentasi dapat disimpulkan bahwa ada dua pokok utama yang saling berhubungan terkait implementasi penilaian autentik ranah pengetahuan pada pembelajaran pendidikan agama Islam di MTsN 2 Palangka Raya sehingga dapat terlaksana secara maksimal. Pertama, kemampuan guru dalam melaksanakan bentuk penilaian pada aspek pengetahuan. Hal itu tercermin dari adanya beberapa tes yang harus dilewati siswa meliputi UTS, UAS, hafalan dan tugas harian, hasil dari semua tes yang dilakukan siswa didistribusikan melalui raport yang akan diterima siswa setiap satu semester. Kedua, ketersediaan buku sebagai penunjang pembelajaran. Namun ketersediaan buku yang belum lengkap tidak menghalangi guru dalam memberikan penilaian, karena guru dapat menggunakan LKS dan memanfaatkan internet untuk mendapat buku yang diinginkan dengan cara mendownload.

\section{Ranah Keterampilan}

Aspek keterampilan KI-4 merupakan salah satu kompetensi yang terdapat dalam kurikulum 2013, bentuk penilaian aspek ini mencakup Tes praktek, proyek dan portofolio. Implementasi penilaian autentik pada aspek keterampilan di MTsN 2 Palangka Raya belum berjalan maksimal. Hal itu terbukti dari tiga bentuk penilaian aspek keterampilan hanya satu bentuk yang sering dilaksanakan oleh guru yaitu tes praktek. Sebagaimana hasil wawancara dengan Bapak M. Isra ${ }^{36}$ (Guru Mata Pelajaran Fiqih) menyatakan bahwa untuk mata pelajaran fiqih penilaian keterampilan dapat dilakukan pada saat anak melakukan praktek ibadah yaitu shalat. Ia juga menyatakan bahwa untuk portofolio belum bisa terlaksana

Namun ada juga sebagian guru yang merasa bingung melaksanakan penilaian aspek keterampilan. Sebagaimana hasil wawancara dengan Ibu Mardiana $^{37}$ menjelaskan bahwa pembelajaran SKI ini prakteknya bingung,

\footnotetext{
${ }^{36}$ Wawancara dengan M. Isra, Guru Mata Pelajaran Fiqih, pada tanggal 6-10 - 2016.

${ }^{37}$ Wawancara dengan Mardiana, Guru Mata Pelajaran SKI, pada tanggal 3 - 10 - 2016.
} 
tidak ada yang dipraktekkan. Begitu juga dengan Portofolio dan proyek. Jadi saya juga bingung.

Berdasarkan hasil wawancara dapat disimpulkan bahwa aspek keterampilan pada pembelajaran pendidikan agama islam di MTsN 2 Palangka Raya belum dilaksanakan secara maksimal. Jadi guru hanya menitik beratkan pada pencapaian dari segi pengetahuan sedangkan aspek keterampilan yang berfungsi sebagai penunjang pengetahuan anak belum dilaksanakan secara maksimal.

\section{Problematika Implementasi Penilaian Autentik dalam Kurikulum 2013}

Penerapan Kurikulum 2013 yang dilaksanakan di MTsN 2 Palangka Raya telah berjalanan dengan baik. Penilaian autentik yang menjadi fokus dalam penelitian ini pun secara umum dimplementasikan oleh para guru PAI yang mencakup kompetensi sikap (sosial dan spiritual), pengetahuan dan keterampilan.

Namun dalam implementasi penilaian autentik masih terdapat beberapa problem/kendala. Kendala-kendala ini ada yang bersifat umum dan ada pula yang bersifat khusus menyangkut penilaian dimaksud. Menurut Kepala MTsN $2^{38}$ kendala-kendala yang dihadapi di antaranya ketersediaan buku, kemampuan guru dalam pengisian raport, guru yang lebih aktif dalam pembelajaran dari pada siswa dan implementasi penilaian itu sendiri.

Kendala umum yang dihadapi guru dalam mengimplementasikan penilaian autentik diantaranya ketersediaan buku penunjang pembelajaran. Sebagaimana hasil wawancara dengan Ibu Mardiana ${ }^{39}$ menyebutkan bahwa kendala K13 itu adalah "ketersediaan bukunya. Di perpus kurang. Jadi pembelajaran hanya mengacu apa yang ada di LKS. Bagaimana di gurunya sebisanya. Buku kendala itu". Lebih rinci Ibu Mastiar ${ }^{40}$ menjelaskan bahwa “Untuk buku tidak semua kelas tersedia. Kelas 1 (7), 2 (8) ada, kelas 9 yang tidak tersedia".

Terkait kekurangan buku penunjang pelaksanaan pembelajaran dalam Kurikulum 2013 ini para guru yang bersangkutan menggunakan LKS maupun

\footnotetext{
${ }^{38}$ Wawancara dengan Kepala MTsN2, pada tanggal 5 - 10 - 2016.

${ }^{39}$ Wawancara dengan Mardiana, Guru Mata Pelajaran SKI, pada tanggal 5 - 10 - 2016.

${ }^{40}$ Wawancara dengan Mastiar, Guru Mata Pelajaran Qur' an Ahdist, pada tanggal 3 - 10 -
} 2016. 
buku-buku yang diunduh melalui aplikasi online. Tentunya hal ini berpengaruh pada hasil pembelajaran yang didapat siswa.

Sedangkan secara khusus kendala yang dihadapi guru menyangkut implementasi penilaian autentik diantaranya kemampuan guru. Para guru PAI menganggap penilaian begitu rumit dan terlalu banyak item yang perlu dinilai. Inilah kesulitan utama yang dihadapi oleh sebagian guru-guru PAI. Hal itu berdasarkan hasil wawancara dengan Ibu Mardiana ${ }^{41}$ (Guru Mata Pelajaran SKI) (3-10-2016) yang menjelaskan bahwa kendala K13 membuat nilainya rumit. Deskripsinya terlalu banyak yang harus menentukan penilaian K13 ini.

Ditinjau secara rinci kendala dari segi kemampuan guru dalam mengimplementasikan penilaian autentik pada pembelajaran pendidikan agama Islam terdapat dua hal pokok yaitu kendala secara teknis dan kendala nonteknis. Kendala teknis yang dihadapi guru dalam melaksanakan penilaian yaitu kemampuan guru dalam menggunakan aplikasi penilaian. Sebagaimana hasil wawancara dengan Bapak M. Isra ${ }^{42}$ menjelaskan bahwa pengetahuan guru dalam mengolah nilai, karena dalam pengolahannya menggunakan aplikasi. Kalo di kota tidak masalah. Tidak ada kendala. Gimana kalo yang di daerah?. Pernyataan yang sama juga disampaikan oleh sebagian guru yang merasa kesulitan dalam menggunakan aplikasi penilaian sehingga implementasi penilaian autentik tidak terlaksana secara maksimal.

Adapun kendala non teknis yang dihadapi guru ialah masalah pemahaman guru tentang penilaian autentik itu sendiri. Banyak dari guru-guru yang masih belum memahami secara mendalam tentang penilaian autentik. Sebagaimana hasil wawancara dengan Bapak Miftah Safingi ${ }^{43}$ mengungkapkan bahwa Problemnya dari materi itu sendiri. Pemahaman materi tentang penilaian autentik perlu disegarkan kembali. kemudian teknik-teknik untuk mendapatkan.

Selama ini para guru PAI lebih mudah dalam melakukan penilaian kompetensi pengetahuan (kognitif), dibandingkan aspek sikap dan keterampilan. Pada aspek sikap dan keterampilan, para guru PAI mengalami kesulitan dalam implementasinya, seperti melaksanakan jurnal guru, pemberian proyek dan portofolio. Sebagaimana Ibu Mardiana ${ }^{44}$ menjelaskan bahwa pembelajaran SKI

\footnotetext{
${ }^{41}$ Wawancara dengan Mardiana, Guru Mata Pelajaran SKI, pada tanggal 3 - 10 - 2016.

${ }^{42}$ Wawancara dengan M. Isra, Guru Mata Pelajaran Fiqih, pada tanggal 6-10 - 2016.

${ }^{43}$ Wawancara dengan Miftah Sangifi, Wakamad Bidang Kurikulum, pada tanggal 3 - 10 2016.

${ }^{44}$ Wawancara dengan Mardiana, Guru Mata Pelajaran SKI, pada tanggal 3 - 10 - 2016.
} 
FITRAH Jurnal Kajian Ilmu-ilmu Keislaman

Vol. 02 No. 2 Desember 2016

ini prakteknya bingung, tidak ada yang dipraktekkan. Begitu juga dengan Portofolio dan proyek. Jadi saya juga bingung.

Meninjau dari beberapa kendala yang dihadapi guru dalam mengimplementasikan penilaian autentik pada pembelajaran agama Islam dapat disimpulkan bahwa kendala yang paling dominan terdapat pada masing-masing guru yaitu kemampuan guru itu sendiri dalam mengimplemantasikannya. Oleh karena itu, sebagai akibatnya penilaian autentik yang dilakukan guru pada pembelajaran pendidikan agama Islam belum berjalan secara optimal.

\section{PENUTUP DAN REKOMENDASI}

Sebagai penutup dari tulisan ini yang merupakan kesimpulan dari penelitian yang penulis lakukan, penulis menyampaikan dua kesimpulan, yakni:

1. Implementasi penilaian autentik Kurikulum 2013 yang dilakukan oleh guru PAI di MTsN 2 Palangka Raya belum berjalan secara optimal. Hal ini terlihat pada penilaian sikap dan keterampilan yang belum terlaksana dengan maksimal, karena sebagian bentuk penilaianya belum dilaksanakan, sedangkan aspek pengetahuan dapat terlaksana dengan baik.

2. Kendala yang dihadapi guru PAI dalam mengimplementasikan penilaian autentik adalah kendala umum dan kendala khusus. Kendala umum adalah ketersedian buku dalam menunjang pembelajaran. Sedangkan kendala khusus adalah kemampuan guru: Pertama, kendala teknis yang terkait kemampuan guru dalam menggunakan aplikasi penilaian; kedua kendala non teknis, yaitu kemampuan guru memahami penilaian autentik.

Selanjutnya, sebagai rekomendai atas hasil penelitian ini maka penuylis menyampaikan bahwa:

1. Perlunya menyegarkan kembali pemahaman dan kemampuan guru-guru PAI terkait penilaian autentik dalam Kurikulum 2013 yang mencakup kompetensi sikap, pengetahuan dan keterampilan. Hal tersebut bisa diwujudkan melalui pendidikan dan pelatihan yang dilaksanakan secara intensif dan berkesinambungan.

2. Peran lembaga terkait yakni Kementrian Agama, Kemendiknas dan para stakeholder dalam peningkatan kapasitas dan kompetensi para guru PAI dalam memahami dan melaksanakan program pembelajaran serta penilaian autentik Kurikulum 2013 secara optimal. 


\section{DAFTAR PUSTAKA}

Abdul Majid. Perencanaan Pembelajaran Mengembangkan Standar Kompetensi Guru. Bandung: PT Remaja RosdaKarya. 2007.

Departemen Agama RI. Al-Qur'an dan Terjemahnya. Jakarta : CV. Nala Dana. 2006.

Imas Kurinasih dan Berlin Sani. Implementasi Kurikulum 2013: Konsep dan Penerapan. Surabaya: Kata Pena. 2014.

Ismet Basuki dan Hariyanto. Asesmen Pembelajaran. Bandung: PT Remaja Rosdakarya. 2014.

Kementerian Agama RI. Penilaian Proses dan Hasil Belajar Modul VI PLPG. 2015.

Keputusan Menteri Agama Nomor 165 Tahun 2014 Tentang Kurikulum 2013 Mata Pelajaran Pendidikan Agama Islam dan Bahasa Arab di Madrasah.

Kokom Komalasari. Pembelajaran Kontekstual: Konsep dan Aplikasi. Bandung: PT Refika Aditama. 2013.

Kunandar. Penilaian Autentik (Penilaian Hasil Belajar Peserta Didik Berdasarkan Kurikulum 2013): Suatu Pendekatan Praktis disertai dengan Contoh, Ed. Rev. Jakarta: Rajawali Pers. 2014.

Salinan Lampiran Peraturan Menteri Pendidikan dan Kebudayaan Republik Indonesia Nomor 66 Tahun 2013 Tentang Standar Penilaian Pendidikan.

Salinan Lampiran Permendikbud Nomor 104 tahun 2014 tentang Penilaian Hasil Belajar oleh Pendidik pada Pendidikan Dasar dan Pendidikan Menengah.

Sugiono. Metode Penelitian Pendidikan Pendekatan Kuantitatif, Kualitatif, dan RED. Bandung: Alfabeta. 2012.

Sunarti dan Selly Rahmawati. Penilaian dalam Kurikulum 2013; Membantu Guru dan Calon Guru Mengetahui Langkah-langkah Penilaian Pembelajaran. Yogyakarta: Andi Offset. 2014.

Undang-Undang Republik Indonesia No.20 Pasal 3 Tahun 2003. 2014. Tentang Sistem Pendidikan Nasional dan Penjelasannya. Semarang: Bina Ilmu.

Zakiah Darajat. Ilmu Pendidikan Islam. Jakarta : Bumi Aksara. 2009. 
FITRAH Jurnal Kajian Ilmu-ilmu Keislaman

Vol. 02 No. 2 Desember 2016

\section{KEBIJAKAN PENGELOLAN PASAR MODERN \\ PERSPEKTIF HUKUM ISLAM}

(Studi Terhadap Peraturan Daerah Kota Palangka Raya Nomor 04 Tahun 2007 tentang Pengelolan Pasar Modern) 